\title{
The Effects of Chronic Acid Loads in Normal Man: Further Evidence for the Participation of Bone Mineral in the Defense against Chronic Metabolic Acidosis*
}

\author{
Jacob Lemann, JR., $\dagger$ John R. Litzow, $\ddagger$ and Edward J. Lennon \\ (From the Department of Internal Medicine and the Clinical Research Center, Marquette \\ University School of Medicine and Milwaukee County Hospital, \\ Milwaukee, Wisc.)
}

Acute acid loads have been shown to titrate extra- and intracellular buffers $(1,2)$. The state of titration of these buffers is reflected by the level of serum bicarbonate. With sustained acid loading, serum bicarbonate ultimately stabilizes at some reduced level despite continuing acid retention, indicating that an additional buffer system is titrated. It has been suggested that such additional quantities of buffer could arise from the slow dissolution of bone mineral during chronic metabolic acidosis (3).

The present metabolic balance studies were carried out to study further the relationship between acid retention and calcium balance during chronic ammonium chloride acidosis.

\section{Methods}

We carried out five metabolic balance studies in healthy men, who were hospitalized in the Clinical Research Center, Marquette University School of Medicine.

General protocol. Each subject ate a constant whole food diet throughout the study. At the start of every experiment, the subject was allowed 3 to 6 days to adjust to his constant diet. Thereafter, each metabolic balance period lasted 6 days. Observations were begun with two to four control periods, followed by three periods of ammonium chloride loading and two to seven recovery periods.

* Submitted for publication April 11, 1966; accepted July $7,1966$.

This investigation was supported in part by grants RO1 AM 08924 and 5 MO1 FR-00058 from the U. S. Public Health Service.

$\dagger$ Address requests for reprints to Dr. Jacob Lemann, Jr., Dept. of Medicine, Milwaukee County General Hospital, 8700 West Wisconsin Avenue, Milwaukee, Wisc. 53266 .

$\$$ Trainee in the Dept. of Medicine, Marquette University School of Medicine, and supported by U. S. Public Health Service training grant 2 T1 AM5023 (e).
Ammonium chloride was placed in tared gelatin capsules and weighed on an analytical balance. Many samples of each batch of $\mathrm{NH}_{4} \mathrm{Cl}$ used were weighed and analyzed for chloride. These analyses indicated an approximate $3 \%$ water content of the chemically pure salt. The water content was taken into account in calculating the dose administered to each subject. The salt was administered in divided doses each day. In order to avoid nausea, the initial daily dose was small and was then progressively increased each day during the first 6 to 9 days of ammonium chloride loading; thereafter, the daily dose was constant. The subjects received one multiple vitamin capsule containing 1,000 USP $U$ of vitamin D daily. Techniques of collection of blood, urine, and stool specimens, analytical methods, and calculations of endogenous production of fixed acid and renal acid excretion and acid balance have been described previously (4). Acid and mineral balances during ammonium chloride loading and recovery periods are presented as changes from the balances observed during control periods.

\section{Results}

Table I presents the mean daily intake, excretion, and balance of electrolytes for the five subjects during control observations. Each subject was in approximate electrolyte balance, with small positive $\mathrm{Na}, \mathrm{K}$, and $\mathrm{Cl}$ balances presumably due to skin losses. Urine and stool composition was normal and appropriate to intake. All subsequent calculations were based on the assumption that the observed control balances would have continued throughout each study if ammonium chloride had not been administered. The results are thus shown as change from control for each subject.

Figure 1 shows some of the major features of the response to $\mathrm{NH}_{4} \mathrm{Cl}$ loading in one of the subjects (R.P.) and is representative of the changes observed in each study. The serum bicarbonate is shown at the top, and the cumulative changes from 
control of acid, calcium, and phosphorus balances are charted below.

During the first 9 days of ammonium chloride loading the dose was increased each day, and there was progressive acid retention accompanied by a progressive fall in the serum bicarbonate concentration. Moderate losses of calcium and phosphorus occurred. During the final 9 days of acid loading, when the daily dose of ammonium chloride was constant, serum bicarbonate actually rose slightly despite continuing acid retention, which averaged $14 \mathrm{mEq}$ per day. Further moderate phosphorus losses were observed, and calcium losses increased sharply. When the acid load was stopped, renal acid excretion remained high during the first recovery period, and despite the fact that cumulative acid balance was never less than $+196 \mathrm{mEq}$, serum bicarbonate rose to and exceeded the control levels. Calcium losses continued, although no additional phosphorus losses were observed. In the final recovery period, serum bicarbonate declined gradually to control as renal acid excretion fell transiently below control and further acid retention occurred. No significant retention of calcium or phosphorus occurred in the second recovery period. At the end of the second recovery period, when serum bicarbonate had returned to stable levels equal to those of the con-

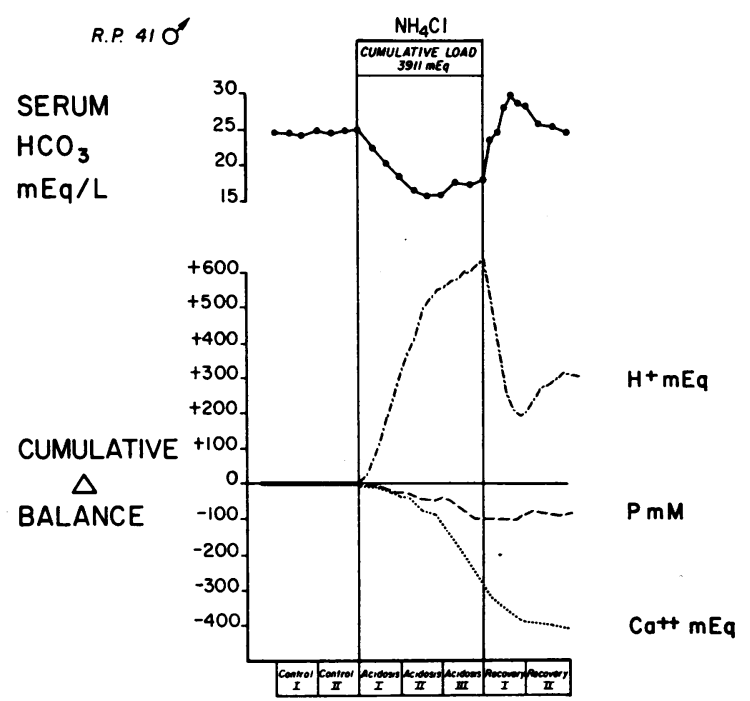

Fig. 1. Serum bicarbonate concentration and cumULATIVE CHANGES FROM CONTROL IN BALANCES OF ACID, CALCIUM, AND PHOSPHORUS DURING CONTROL, AMMONIUM CHLORIDE LOADING, AND RECOVERY PERIODS.
TABLE I

Control observations

\begin{tabular}{lcccccc}
\hline \hline & $\mathrm{Na}$ & $\mathrm{K}$ & $\mathrm{Ca}$ & $\mathrm{Mg}$ & $\mathrm{Cl}$ & $\mathrm{P}$ \\
\hline & & \multicolumn{7}{c}{$m E q /$ day } & & mmoles/day \\
Diet & 158 & 78 & 44 & 22 & 157 & 38 \\
Urine & 144 & 64 & 8 & 10 & 152 & 25 \\
Stool & 1 & 7 & 38 & 12 & 1 & 11 \\
Balances* & $+13 \pm 8$ & $+7 \pm 5$ & $-2 \pm 7$ & $0 \pm 2$ & $+4 \pm 6$ & $+2 \pm 2$ \\
\hline
\end{tabular}

* Mean \pm standard deviation.

trol periods, the cumulative acid balance was $+310 \mathrm{mEq}$, whereas cumulative calcium and phosphorus balances were $-406 \mathrm{mEq}$ and -86 mmoles, respectively.

Table II presents the complete balance data for another subject (A.H.) during four control, three $\mathrm{NH}_{4} \mathrm{Cl}$ loading, and seven recovery periods. These results are typical of each of the five studies. Body weight and blood measurements are given for the morning of the first day of each period. Urinary $\left[\mathrm{H}^{+}\right]$and $\mathrm{pH}$ are the average values for each 6-day period. All other constituents are given as total amounts per period.

The quantity of $\mathrm{NH}_{4} \mathrm{Cl}$ administered to A.H. during each of the three loading periods is shown in the center of Table II. Serum bicarbonate fell progressively as acid was retained during the first two ammonium chloride loading periods. During the final period, serum bicarbonate rose slightly despite continuous retention of acid that averaged $+14 \mathrm{mEq}$ per day. During acid loading, calcium and phosphorus balances became negative as a result of urinary losses. Urinary calcium losses continued in the first recovery period. At the end of the second recovery period, when serum bicarbonate had returned to stable control levels, the cumulative change in acid balance was $+360 \mathrm{mEq}$, whereas the cumulative changes in calcium and phosphorus balances were $-194 \mathrm{mEq}$ and -56 mmoles, respectively.

During five additional recovery periods, acid balance was essentially equal to that observed in the control periods, so that the cumulative acid balance changed by only $+53 \mathrm{mEq}$ during these final 30 days. The cumulative change in acid balance was thus $+413 \mathrm{mEq}$ at the end of the entire study. The cumulative changes in calcium and phosphorus balances were $+50 \mathrm{mEq}$ and +50 mmoles, respectively, during these recovery periods. At the end of the study, the cumulative 
TABLE II

Experimental data*

\begin{tabular}{|c|c|c|c|c|c|c|c|c|c|c|c|c|c|}
\hline & & \multirow[b]{2}{*}{ Weight $\dagger$} & \multicolumn{10}{|c|}{ Blood $\ddagger$} & \multirow[b]{2}{*}{$\underset{\text { fed }}{\mathrm{NH}_{4} \mathrm{Cl}}$} \\
\hline & & & {$\left[\mathrm{H}^{+}\right]$} & $\mathrm{HCO}_{3}$ & $\mathrm{PcO}_{2}$ & $\mathrm{Na}$ & $\mathrm{K}$ & $\mathrm{Cl}$ & $\mathrm{Ca}$ & $\mathbf{M g}$ & $\mathbf{P}$ & $\begin{array}{l}\text { Creat- } \\
\text { inine }\end{array}$ & \\
\hline & & $k g$ & $n E q / L$ & $m E q / L$ & $m m \mathrm{Hg}$ & \multicolumn{4}{|c|}{$m E q / L$} & & \multicolumn{2}{|c|}{$\underset{m l}{m g / 100}$} & $\underset{\text { period }}{m E q /}$ \\
\hline Control & $\begin{array}{c}\text { II } \\
\text { III } \\
\text { IV }\end{array}$ & $\begin{array}{l}69.34 \\
68.80 \\
68.30 \\
68.42\end{array}$ & $\begin{array}{l}40.7 \\
42.6 \\
39.8 \\
40.7\end{array}$ & $\begin{array}{l}27.2 \\
26.6 \\
28.8 \\
28.9\end{array}$ & $\begin{array}{l}46 \\
47 \\
48 \\
49\end{array}$ & $\begin{array}{l}144 \\
144 \\
142 \\
143\end{array}$ & $\begin{array}{l}4.0 \\
4.3 \\
4.7 \\
4.2\end{array}$ & $\begin{array}{l}105 \\
106 \\
107 \\
107\end{array}$ & $\begin{array}{l}4.84 \\
4.83 \\
4.86 \\
5.03\end{array}$ & $\begin{array}{l}1.80 \\
1.80 \\
1.79 \\
1.84\end{array}$ & $\begin{array}{l}2.7 \\
2.8 \\
2.8 \\
2.8\end{array}$ & $\begin{array}{l}1.3 \\
1.3 \\
1.3 \\
1.3\end{array}$ & \\
\hline Mean con & & 68.72 & 41.0 & 27.9 & 48 & 143 & 4.3 & 106 & 4.89 & 1.81 & 2.8 & 1.3 & \\
\hline $\mathrm{NH}_{4} \mathrm{Cl}$ & $\begin{array}{r}\text { I } \\
\text { II } \\
\text { III }\end{array}$ & $\begin{array}{l}68.18 \\
66.80 \\
66.29\end{array}$ & $\begin{array}{l}42.6 \\
50.1 \\
52.5\end{array}$ & $\begin{array}{l}28.9 \\
21.1 \\
18.8\end{array}$ & $\begin{array}{l}52 \\
44 \\
41\end{array}$ & $\begin{array}{l}140 \\
138 \\
141\end{array}$ & $\begin{array}{l}4.0 \\
3.9 \\
3.5\end{array}$ & $\begin{array}{l}106 \\
114 \\
120\end{array}$ & $\begin{array}{l}4.87 \\
4.70 \\
4.62\end{array}$ & $\begin{array}{l}1.64 \\
1.70 \\
1.64\end{array}$ & $\begin{array}{l}2.8 \\
2.7 \\
2.0\end{array}$ & $\begin{array}{l}1.3 \\
1.3 \\
1.2\end{array}$ & $\begin{array}{r}733 \\
1,304 \\
1,304\end{array}$ \\
\hline Recovery & $\begin{array}{r}\text { I } \\
\text { II } \\
\text { III } \\
\text { IV } \\
\text { V } \\
\text { VI } \\
\text { VII }\end{array}$ & $\begin{array}{l}65.88 \\
67.14 \\
66.82 \\
66.42 \\
66.35 \\
66.10 \\
65.77 \\
65.70\end{array}$ & $\begin{array}{l}52.5 \\
35.5 \\
39.8 \\
42.6 \\
39.8 \\
42.6 \\
38.0 \\
41.7\end{array}$ & $\begin{array}{l}19.9 \\
34.3 \\
29.5 \\
28.3 \\
28.8 \\
29.0 \\
27.8 \\
27.2\end{array}$ & $\begin{array}{l}44 \\
51 \\
49 \\
50 \\
48 \\
52 \\
44 \\
47\end{array}$ & $\begin{array}{l}141 \\
145 \\
141 \\
142 \\
142 \\
142 \\
141 \\
142\end{array}$ & $\begin{array}{l}3.5 \\
3.8 \\
4.4 \\
4.0 \\
4.3 \\
4.1 \\
4.3 \\
4.6\end{array}$ & $\begin{array}{l}115 \\
103 \\
108 \\
105 \\
107 \\
107 \\
108 \\
109\end{array}$ & $\begin{array}{l}4.85 \\
4.88 \\
4.90 \\
4.91 \\
4.91 \\
4.93 \\
4.93\end{array}$ & $\begin{array}{l}1.80 \\
1.90 \\
1.76 \\
1.74\end{array}$ & $\begin{array}{l}1.9 \\
2.7 \\
2.9 \\
3.0 \\
3.0 \\
3.1 \\
3.0\end{array}$ & $\begin{array}{l}1.2 \\
1.3 \\
1.2 \\
1.3 \\
1.3 \\
1.2 \\
1.3\end{array}$ & \\
\hline
\end{tabular}

* The constant diet provided during each 6-day period: $\mathrm{Na}, 846 ; \mathrm{K}, 384 ; \mathrm{Ca}, 139 ; \mathrm{Mg}, 111 ;$ and $\mathrm{Cl}, 828 \mathrm{mEq} ;$ and $\mathrm{P}, 178 \mathrm{mmoles}$; $\mathrm{Cl}$ intake increased by the amounts shown during the $\mathrm{NH}_{4} \mathrm{Cl}$ loading periods.

+ Weight on the first day of each 6-day period.

$\$$ Blood values for the first day of each 6-day period.
\$ See Methods for calculations. TA $=$ titratable acidity, OA = organic acid.

change in calcium balance was $-144 \mathrm{mEq}$ and in phosphorus balance, -6 mmoles.

Table III shows the mean body weight and blood values for all five subjects during the control, acid loading, and first two recovery periods. Their patterns of response to $\mathrm{NH}_{4} \mathrm{Cl}$ loading and recovery are identical to those presented for subjects R.P. (Figure 1) and A.H. (Table II).

Table IV shows the mean changes from control in stool composition during acid loading and the first two recovery periods. At the end of acid loading, the cumulative change in calculated fecal content of excess combustible anions was $-90 \pm$ $54 \mathrm{mEq}$ and was significantly different from zero $(p<0.05)$. At the end of the second recovery period, as shown in the last two lines of Table IV, there were no significant cumulative changes in any of the inorganic constituents. The final cumulative change in combustible anion was still -79 $\mathrm{mEq}$, but it was no longer statistically significant because of variations among subjects.

Table $\mathrm{V}$ presents the mean changes in electrolyte balances. The general pattern observed was identical to those shown for R.P. (Figure 1) and A.H. (Table II). At the end of the second recovery period, when blood $\left[\mathrm{H}^{+}\right]$and serum $\left[\mathrm{HCO}_{3}{ }^{-}\right]$had returned to and stabilized at control levels, the only significant changes in cumulative balances were those observed for calcium and phosphorus.

Nitrogen balances were measured in two of the

TABLE III

Mean body weight and blood values*

\begin{tabular}{|c|c|c|c|c|c|c|c|c|c|c|c|c|}
\hline . & & Weight & {$\left[\mathrm{H}^{+}\right]$} & {$\left[\mathrm{HCO}_{3}-\right]$} & $\mathrm{PCO}_{2}$ & $\mathrm{Na}$ & $\mathrm{K}$ & $\mathrm{Cl}$ & $\mathrm{Ca}$ & $\mathbf{M g}$ & $\mathbf{P}$ & Creatinine \\
\hline & & $k g$ & $n E q / L$ & $m E q / L$ & $m m \mathrm{Hg}$ & & & $m E q / L$ & & & \multicolumn{2}{|c|}{$m g / 100 \mathrm{ml}$} \\
\hline Controlt & & 68.62 & 40.5 & 26.5 & 45 & 141 & 4.2 & 105 & 4.8 & 1.7 & 3.7 & 1.1 \\
\hline $\mathrm{NH}_{4} \mathrm{Cl}$ period & II I & $\begin{array}{l}68.58 \\
67.81 \\
67.25\end{array}$ & $\begin{array}{l}39.5 \\
49.0 \\
50.4\end{array}$ & $\begin{array}{r}26.5 \\
19.9 \\
18.8\end{array}$ & $\begin{array}{l}44 \\
41 \\
40\end{array}$ & $\begin{array}{l}140 \\
139 \\
141\end{array}$ & $\begin{array}{l}4.1 \\
4.0 \\
3.7\end{array}$ & $\begin{array}{l}105 \\
112 \\
116\end{array}$ & $\begin{array}{l}4.8 \\
4.7 \\
4.7\end{array}$ & $\begin{array}{l}1.7 \\
1.6 \\
1.6\end{array}$ & $\begin{array}{l}3.7 \\
3.4 \\
3.2\end{array}$ & $\begin{array}{l}1.1 \\
1.1 \\
1.1\end{array}$ \\
\hline Recovery period & II & $\begin{array}{l}67.14 \\
68.74\end{array}$ & $\begin{array}{l}48.4 \\
36.1\end{array}$ & $\begin{array}{r}19.3 \\
31.1\end{array}$ & $\begin{array}{l}39 \\
47\end{array}$ & $\begin{array}{l}141 \\
142\end{array}$ & $\begin{array}{l}3.5 \\
4.1\end{array}$ & $\begin{array}{l}114 \\
102\end{array}$ & $\begin{array}{l}4.7 \\
4.9\end{array}$ & $\begin{array}{l}1.8 \\
1.8\end{array}$ & $\begin{array}{l}3.0 \\
4.0\end{array}$ & $\begin{array}{l}1.0 \\
1.2\end{array}$ \\
\hline End recovery & II & 68.32 & 38.1 & 27.7 & 45 & 142 & 4.3 & 104 & 4.8 & 1.7 & 3.8 & 1.2 \\
\hline
\end{tabular}

* All values beyond the first line are for the morning of the first day of each 6-day period.

$\dagger$ Mean values for measurements in all control periods. 
TABLE II

for subject $A . H$.

\begin{tabular}{|c|c|c|c|c|c|c|c|c|c|c|c|c|c|c|c|c|c|c|c|c|}
\hline \multicolumn{15}{|c|}{ Urine } & \multirow{2}{*}{\multicolumn{6}{|c|}{ Stool }} \\
\hline \multirow[b]{2}{*}{$\mathrm{pH}$} & \multirow[b]{2}{*}[\mathrm{H}^{+}]{} & \multirow[b]{2}{*}{ TA\& } & \multirow[b]{2}{*}{$\mathrm{NH}_{4}$} & \multirow[b]{2}{*}{$\mathrm{HCO}_{3}$} & \multirow{2}{*}{$\begin{array}{l}\text { Net } \\
\text { acid }\end{array}$} & \multirow[b]{2}{*}{ SO. } & \multirow{2}{*}{$\begin{array}{c}\text { OA } \\
\text { salts\& }\end{array}$} & \multirow{2}{*}{$\begin{array}{l}\text { Total } \\
\text { creat- } \\
\text { inine }\end{array}$} & \multirow[b]{2}{*}{$\mathrm{Na}$} & \multirow[b]{2}{*}{$\mathbf{K}$} & \multirow[b]{2}{*}{$\mathrm{Ca}$} & \multirow[b]{2}{*}{$\mathbf{M g}$} & \multirow[b]{2}{*}{$\mathrm{Cl}$} & \multirow[b]{2}{*}{$\mathbf{P}$} & & & & & & \\
\hline & & & & & & & & & & & & & & & $\mathrm{Na}$ & $\mathbf{K}$ & $\mathrm{Ca}$ & $\mathbf{M g}$ & $\mathrm{Cl}$ & $\mathbf{P}$ \\
\hline \multicolumn{3}{|c|}{$n E Q / L$} & \multicolumn{4}{|c|}{$m E q /$ period } & \multicolumn{3}{|c|}{$\begin{array}{c}\text { mmoles/ } \\
\text { period }\end{array}$} & \multicolumn{3}{|c|}{$m E q /$ period } & \multicolumn{3}{|c|}{$\underset{\text { period }}{\text { mmoles/ }}$} & \multicolumn{3}{|c|}{$m E q /$ period } & \multicolumn{2}{|c|}{$\begin{array}{c}\text { moriod } \\
\text { periols }\end{array}$} \\
\hline $\begin{array}{l}5.83 \\
5.64 \\
5.67 \\
5.70\end{array}$ & $\begin{array}{l}1,470 \\
2,300 \\
2,160 \\
1,970\end{array}$ & $\begin{array}{r}91 \\
110 \\
100 \\
91\end{array}$ & $\begin{array}{l}165 \\
147 \\
182 \\
176\end{array}$ & $\begin{array}{l}6 \\
0 \\
0 \\
1\end{array}$ & $\begin{array}{l}250 \\
257 \\
282 \\
266\end{array}$ & $\begin{array}{l}197 \\
215 \\
200 \\
193\end{array}$ & $\begin{array}{l}175 \\
185 \\
176 \\
168\end{array}$ & $\begin{array}{l}78 \\
78 \\
76 \\
77\end{array}$ & $\begin{array}{l}809 \\
805 \\
675 \\
760\end{array}$ & $\begin{array}{l}274 \\
311 \\
304 \\
295\end{array}$ & $\begin{array}{l}21 \\
20 \\
28 \\
21\end{array}$ & $\begin{array}{l}76 \\
68 \\
67 \\
62\end{array}$ & $\begin{array}{l}825 \\
854 \\
740 \\
817\end{array}$ & $\begin{array}{l}119 \\
132 \\
120 \\
111\end{array}$ & $\begin{array}{l}3 \\
7 \\
5 \\
6\end{array}$ & $\begin{array}{l}56 \\
59 \\
46 \\
44\end{array}$ & $\begin{array}{l}134 \\
134 \\
141 \\
127\end{array}$ & $\begin{array}{l}51 \\
59 \\
49 \\
44\end{array}$ & $\begin{array}{l}3 \\
4 \\
2 \\
2\end{array}$ & $\begin{array}{l}80 \\
62 \\
51 \\
48\end{array}$ \\
\hline 5.70 & 1,975 & 98 & 168 & 2 & 264 & 201 & 176 & 77 & 762 & 296 & 22 & 68 & 809 & 120 & 5 & 51 & 134 & 51 & 3 & 60 \\
\hline $\begin{array}{l}5.15 \\
5.25 \\
5.44\end{array}$ & $\begin{array}{l}7,090 \\
5,600 \\
3,660\end{array}$ & $\begin{array}{l}138 \\
160 \\
122\end{array}$ & $\begin{array}{r}479 \\
1,232 \\
1,364\end{array}$ & $\begin{array}{l}0 \\
0 \\
0\end{array}$ & $\begin{array}{r}617 \\
1,392 \\
1,486\end{array}$ & $\begin{array}{l}214 \\
243 \\
228\end{array}$ & $\begin{array}{l}162 \\
165 \\
171\end{array}$ & $\begin{array}{l}77 \\
76 \\
76\end{array}$ & $\begin{array}{l}972 \\
726 \\
752\end{array}$ & $\begin{array}{l}432 \\
485 \\
292\end{array}$ & $\begin{array}{r}43 \\
87 \\
115\end{array}$ & $\begin{array}{l}73 \\
68 \\
65\end{array}$ & $\begin{array}{l}1,507 \\
2,068 \\
2,108\end{array}$ & $\begin{array}{l}139 \\
174 \\
136\end{array}$ & $\begin{array}{l}4 \\
1 \\
2\end{array}$ & $\begin{array}{l}54 \\
18 \\
51\end{array}$ & $\begin{array}{r}122 \\
42 \\
116\end{array}$ & $\begin{array}{l}40 \\
17 \\
48\end{array}$ & $\begin{array}{l}2 \\
1 \\
1\end{array}$ & $\begin{array}{l}62 \\
22 \\
59\end{array}$ \\
\hline $\begin{array}{l}5.84 \\
6.40 \\
5.97 \\
5.83 \\
5.68 \\
5.79 \\
5.86\end{array}$ & $\begin{array}{r}1,430 \\
400 \\
1,080 \\
1,480 \\
2,110 \\
1,630 \\
1,390\end{array}$ & $\begin{array}{l}65 \\
50 \\
69 \\
87 \\
93 \\
85 \\
85\end{array}$ & $\begin{array}{l}638 \\
123 \\
169 \\
189 \\
214 \\
206 \\
203\end{array}$ & $\begin{array}{r}4 \\
66 \\
27 \\
13 \\
3 \\
10 \\
10\end{array}$ & $\begin{array}{l}699 \\
107 \\
211 \\
263 \\
304 \\
281 \\
278\end{array}$ & $\begin{array}{l}189 \\
170 \\
176 \\
186 \\
205 \\
205 \\
197\end{array}$ & $\begin{array}{l}171 \\
209 \\
233 \\
203 \\
196 \\
210 \\
206\end{array}$ & $\begin{array}{l}76 \\
77 \\
75 \\
78 \\
73 \\
74 \\
72\end{array}$ & $\begin{array}{l}502 \\
912 \\
762 \\
762 \\
842 \\
796 \\
777\end{array}$ & $\begin{array}{r}58 \\
246 \\
317 \\
317 \\
299 \\
306 \\
295\end{array}$ & $\begin{array}{l}66 \\
30 \\
19 \\
16 \\
12 \\
17 \\
12\end{array}$ & $\begin{array}{l}51 \\
62 \\
61 \\
65 \\
64 \\
68 \\
65\end{array}$ & $\begin{array}{l}892 \\
815 \\
785 \\
780 \\
872 \\
806 \\
789\end{array}$ & $\begin{array}{l}80 \\
94 \\
94 \\
113 \\
112 \\
108 \\
109\end{array}$ & $\begin{array}{r}9 \\
13 \\
12 \\
5 \\
8 \\
8 \\
5\end{array}$ & $\begin{array}{c}104 \\
64 \\
36 \\
51 \\
38 \\
46 \\
51\end{array}$ & $\begin{array}{r}240 \\
118 \\
65 \\
126 \\
108 \\
134 \\
221\end{array}$ & $\begin{array}{r}114 \\
59 \\
29 \\
50 \\
40 \\
50 \\
85\end{array}$ & $\begin{array}{l}2 \\
4 \\
5 \\
2 \\
2 \\
3 \\
4\end{array}$ & $\begin{array}{r}126 \\
69 \\
36 \\
65 \\
51 \\
60 \\
102\end{array}$ \\
\hline
\end{tabular}

five subjects. Moderate losses of nitrogen occurred during acid loading, but at the end of the second recovery period, 30 days after $\mathrm{NH}_{4} \mathrm{Cl}$ loading began, the cumulative changes in nitrogen balances were only -0.9 and $-6.8 \mathrm{~g}$.

We have shown previously (4) that when whole food diets are fed it is necessary to take into account the combustible anion (potential alkali) content of both diet and stool in calculating net fixed acid production. Table VI shows the mean changes in the constituents of the acid balance from control values during acid loading and the first two recovery periods. There were small variations in the sum of urinary inorganic sulfate plus organic acid salts, but at the end of the second recovery period no cumulative change was found. Since the diet was constant, only the change from control in stool combustible anion content is shown. This decreased significantly during acid loading, and the cumulative reduction at the end of the second recovery period was 79 $\mathrm{mEq}$. The subjects received a total load of 3,504 $\mathrm{mEq}$ of $\mathrm{NH}_{4} \mathrm{Cl}$ (range 3,015 to $3,911 \mathrm{mEq}$ ) on the average. Thus, net fixed acid production rose progressively during acid loading but was close to control in the recovery periods. The cumulative change in acid production was $+3,425 \mathrm{mEq}$ at the end of the second recovery period. Renal acid

TABLE IV

Mean change from control in stool composition per 6-day metabolic period

\begin{tabular}{|c|c|c|c|c|c|c|c|c|}
\hline & & $\mathrm{Na}$ & $\mathbf{K}$ & $\mathrm{Ca}$ & $\mathbf{M g}$ & $\mathrm{Cl}$ & $\mathbf{P}$ & $\begin{array}{c}\text { Combustible } \\
\text { anions* }\end{array}$ \\
\hline $\mathrm{NH}_{4} \mathrm{Cl}$ period & $\begin{array}{l}\text { I } \\
\text { II } \\
\text { III }\end{array}$ & $\begin{array}{l}-4 \\
-5 \\
-4\end{array}$ & $\begin{array}{r}-9 \\
-17 \\
-9\end{array}$ & $\begin{aligned} & m E q \\
- & 38 \\
- & 25 \\
- & 10\end{aligned}$ & $\begin{array}{r}-16 \\
-14 \\
-3\end{array}$ & $\begin{array}{r}-1 \\
-2 \\
0\end{array}$ & $\begin{array}{l}\text { mmoles } \\
-13 \\
-15 \\
-6\end{array}$ & $\begin{aligned} & m E q \\
&- 43 \\
&-32 \\
&-15\end{aligned}$ \\
\hline Recovery period & II & $\begin{array}{l}+2 \\
+2\end{array}$ & $\begin{array}{l}+7 \\
+1\end{array}$ & $\begin{array}{l}-3 \\
+6\end{array}$ & $\begin{array}{l}+7 \\
-7\end{array}$ & $\begin{array}{r}-1 \\
0\end{array}$ & $\begin{array}{l}+9 \\
-6\end{array}$ & $\begin{array}{r}-2 \\
+13\end{array}$ \\
\hline $\begin{array}{l}\text { Cumulative } \Delta \text { from } \\
\text { control at end of } \\
\text { recovery II }\end{array}$ & $\mathrm{p} \dagger$ & ${ }_{\mathrm{NS}}^{-9 \pm 12}$ & $-\underset{N S}{ \pm} 48$ & $-70 \underset{\mathrm{NS}}{ \pm} 124$ & $\underset{\text { NS }}{-33 \pm 59}$ & $\stackrel{-4}{N S}^{ \pm} 4$ & $-\underset{N S}{ \pm}=95$ & $\underset{\text { NS }}{-79}$ \\
\hline
\end{tabular}

$*[\mathrm{Na}+\mathrm{K}+\mathrm{Ca}+\mathrm{Mg}]-[\mathrm{Cl}+1.8 \mathrm{P}]$.

$\dagger$ Probability that the mean change does not differ from zero. Values $>0.05$ are considered nonsignificant. 
TABLE $V$

Mean change in balance from control per 6-day metabolic period

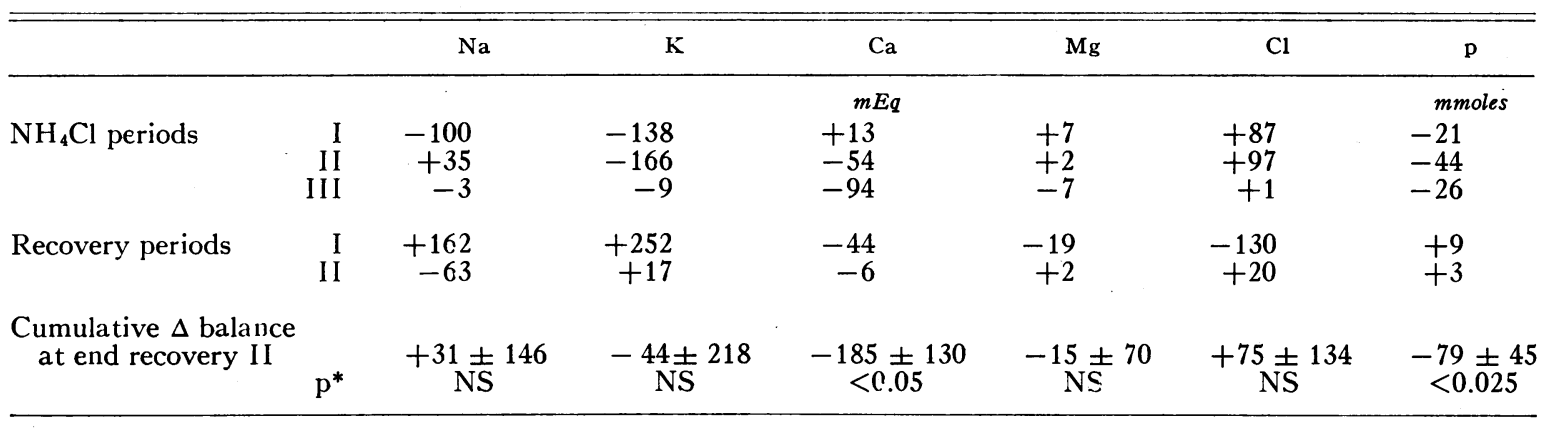

* Probability that the mean change does not differ from zero.

excretion rose progressively during acid loading so that the rate at which acid was accumulating in the body (e.g., the acid balance per period) declined. Nonetheless, as reported previously (3), acid balance was significantly positive during the third period of acid loading, averaging $+10 \pm 5$ $\mathrm{mEq}$ per day $(\mathrm{p}<0.025)$, despite the fact that the serum $\left[\mathrm{HCO}_{3}^{-}\right]$was actually rising slightly. In the first recovery period acid excretion remained high, but in the second it fell below control levels. At the end of the second recovery period, acid balance was significantly positive, averaging $+193 \pm$ $126 \mathrm{mEq}(\mathrm{p}<0.025)$.

The possible cumulative errors of prolonged metabolic balance studies are well known. In the present studies these were obviated in part by presenting all balance data as changes from control observations. In three of the five subjects, additional balance observations were continued beyond the second recovery period; the mineral and acid balances during these additional recovery periods were virtually identical with those of the control periods. These observations and the findings of significant positive acid balance and significant negative calcium and phosphorus balances in each of the five studies suggest that the results reported are not an artifact of cumulative analytical error.

\section{Discussion}

The present studies were carried out to evaluate further the role of buffering by bone mineral in the defense against chronic metabolic acidosis. Constant whole food diets, which approximated the usual diets of the subjects, provided adequate intakes of calcium and phosphorus, and yielded normally formed stools, were used.

We evaluated the responses to induced metabolic acidosis by comparing the observed changes in net renal acid excretion from control values to the changes in net fixed acid production, including diet and stool unmeasured anion, as before (4).

Despite the return of serum bicarbonate levels to stable values equal to those of the control periods, the cumulative increase in renal acid excretion by the end of the second recovery period failed

TABLE VI

Mean change in the parameters of acid balance per 6-day metabolic period

\begin{tabular}{|c|c|c|c|c|c|c|}
\hline & $\begin{array}{l}\text { Urine } \\
\mathrm{SO}_{4}^{-}+\mathrm{OA}^{-}\end{array}$ & $\begin{array}{l}\text { Stool organic } \\
\text { anion excretion }\end{array}$ & $\underset{\text { fed }}{\mathrm{NH}_{4} \mathrm{Cl}}$ & $\begin{array}{l}\text { Net fixed } \\
\text { acid production }\end{array}$ & $\begin{array}{l}\text { Renal acid } \\
\text { excretion }\end{array}$ & Acid balance \\
\hline & \multicolumn{6}{|c|}{$m E q$} \\
\hline $\begin{array}{l}\mathrm{NH}_{4} \mathrm{Cl} \text { periods } \\
\\
\text { II } \\
\text { III }\end{array}$ & $\begin{array}{l}-13 \\
+16 \\
+24\end{array}$ & $\begin{array}{l}-43 \\
-32 \\
-15\end{array}$ & $\begin{array}{r}733 \\
1,369 \\
1,402\end{array}$ & $\begin{array}{r}+677 \\
+1,353 \\
+1,411\end{array}$ & $\begin{array}{r}+381 \\
+1,186 \\
+1,354\end{array}$ & $\begin{array}{r}+296 \\
+167 \\
+57\end{array}$ \\
\hline Recovery periods II & $\begin{array}{l}-13 \\
-14\end{array}$ & $\begin{array}{r}-2 \\
+13\end{array}$ & $\begin{array}{l}0 \\
0\end{array}$ & $\begin{array}{r}-15 \\
-1\end{array}$ & $\begin{array}{l}+429 \\
+118\end{array}$ & $\begin{array}{l}-444 \\
+117\end{array}$ \\
\hline $\begin{array}{l}\text { Cumulative } \Delta \text { at } \\
\text { end recovery II } \\
\mathrm{p}^{*}\end{array}$ & $\begin{array}{l}0 \pm 81 \\
\mathrm{NS}\end{array}$ & $\begin{array}{c}-79 \pm 76 \\
\text { NS }\end{array}$ & 3,504 & $+3,425$ & $+3,232$ & $\begin{array}{c}+193 \pm 126 \\
<0.025\end{array}$ \\
\hline
\end{tabular}

* Probability that the mean does not differ from zero. 
to account for an average of $193 \mathrm{mEq}$ of the cumulative increase in net fixed acid production.

In each study the serum bicarbonate became stable at a reduced level after the first period of ammonium chloride administration, despite the fact that significant acid retention continued. The additional quantities of acid retained, without further fall in serum bicarbonate, must have titrated some buffers other than those of extra- and intracellular water.

An examination of the observed mineral balances (Table V) provides information about the possible sequential distribution of the retained acid. During the first acidosis period, sodium and potassium losses were marked, but calcium balances remained at control values. Chloride. was retained as the serum chloride rose, and modest phosphorus losses occurred. During the second acidosis period, potassium and calcium were lost without further losses of sodium. Chloride retention and phosphorus losses continued. In the final acidosis period, calcium was the only cation lost. No further changes in chloride balance occurred, whereas phosphorus losses continued. No significant changes in magnesium balance were found. The pattern observed suggested that extra- and intracellular buffers shared equally in the neutralization of the acid load during the first ammonium chloride period, but after extracellular buffers had become significantly titrated, cell buffers plus bone, and finally only bone, continued to provide buffer reserves.

During the first two recovery periods, sodium and potassium losses were promptly replaced, and the retained chloride was excreted. The rapid restoration of sodium and potassium stores and the prompt rise of serum bicarbonate indicated that extra- and intracellular fluid buffers were quickly replaced. Since calcium balance was also negative during the first recovery period, it is possible that continuing liberation of alkali from bone mineral contributed to the rapid restoration of cell and extracellular fluid buffers. Despite the replenishment of these buffer stores an average of $193 \mathrm{mEq}$ of acid had apparently been retained at the end of the second recovery period; this was accompanied only by the significant loss of 185 $\mathrm{mEq}$ of calcium and 79 mmoles of phosphorus.

During the three $\mathrm{NH}_{4} \mathrm{Cl}$ loading periods, a statistically significant cumulative reduction in fecal "unmeasured anion" content that averaged $90 \mathrm{mEq}$ per subject $(\mathrm{p}<0.05)$ was observed, indicating a decreased loss of potential alkali from the gut during acidosis. A small increase in fecal unmeasured anion excretion occurred during the first two recovery periods. Thus, fecal excretion of combustible anions may be altered by the state of systemic acid-base balance.

Another striking finding in these studies was the marked calcium losses in the urine that occurred when acidosis was induced. It has long been known that experimental acidosis induces a negative calcium balance due entirely to hypercalciuria in normal subjects (5) and that an acid environment in vivo (6) results in dissolution of bone mineral. Furthermore, Dennig, Dill, and Talbott (7), and later Albright and Reifenstein (8), recognized that release of bone calcium salts into body fluids would inevitably contribute alkali. More recently, this mechanism has again been invoked as the explanation for the finding of continuous acid retention in experimental chronic metabolic acidosis (3). Previous interpretations of the significance of the calcium losses that occur during chronic metabolic acidosis varied. Dennig and co-workers assumed, on the basis of their study (7) in which the molar ratio of $\mathrm{Ca} / \mathrm{P}$ lost was 0.84 , that all of the calcium losses arose from bone $\mathrm{Ca}_{3}\left(\mathrm{PO}_{4}\right)_{2}$, and hence each milliequivalent of calcium lost would represent buffering of only $0.4 \mathrm{mEq}$ of acid. Albright and Reifenstein (8) assumed that the calcium losses in acidosis were derived from bone salts in the same proportion as these salts existed in whole bone and thus calculated that $0.49 \mathrm{mEq}$ of acid would be neutralized for each milliequivalent of calcium lost. However, direct measurements of the alterations in bone composition during relatively acute experimental metabolic acidosis in animals (9) indicate that $\mathrm{CaCO}_{3}$ is the principal calcium salt lost. In more prolonged acidosis occurring during the course of chronic renal disease in man, it is clear that the total mineral mass of the skeleton is reduced, but even in this circumstance disproportionate losses of carbonate from bone have been reported (10). Losses of $\mathrm{CaCO}_{3}$ from the skeleton would result in the neutralization of $1 \mathrm{mEq}$ of acid for each milliequivalent of calcium lost. In the present studies the molar ratio of $\mathrm{Ca} / \mathrm{P}$ lost by the end of the second recovery period averaged $1.17 / 1$, which might be taken as evidence that only $\mathrm{Ca}_{3}\left(\mathrm{PO}_{4}\right)_{2}$ was lost from bone. However, the data show that calcium 
and phosphorus losses did not occur simultaneously, as might have been expected if $\mathrm{Ca}_{3}\left(\mathrm{PO}_{4}\right)$ was liberated into body fluids and excreted simultaneously. Instead, phosphorus losses began immediately with acid loading and stopped abruptly when the load was discontinued, whereas calcium losses rose slowly and progressively during acidosis and gradually declined to control late in the first recovery period. Furthermore, additional balance observations in two of the subjects for 30 days beyond the end of the second recovery period indicated that the phosphorus losses were ultimately restored, although significant calcium losses persisted. In these subjects, at the end of the second recovery period, the cumulative changes in calcium and phosphorus balances from control averaged $-135 \mathrm{mEq}$ and -40 mmoles, respectively. Thirty days later, calcium balance still averaged $-93 \mathrm{mEq}$, whereas phosphorus balance averaged +20 mmoles. Although calcium losses of the magnitude observed in our studies could only have come from bone, the abundant stores of phosphorus in cells could have provided part or all of the observed phosphorus losses. Since acidosis was maintained for only 18 days, it seems reasonable to speculate that a significant fraction of the observed calcium losses may have been derived from bone $\mathrm{CaCO}_{3}$. In any event, it is clear that bone mineral participated in the defense against the induced acidosis.

\section{Summary}

We carried out metabolic balance studies in five normal subjects to investigate the nature of the buffers utilized in the defense against chronic ammonium chloride acidosis and to determine the mechanisms responsible for the ultimate disposal of the administered acid.

Initially, as in studies of acute metabolic acidosis, acid was retained and appeared to titrate extraand intracellular buffer systems. As acid retention continued, intracellular and bone buffers and, finally, bone mineral alone, appeared to provide additional buffer reserves. When the acid load was stopped, extra- and intracellular buffers appeared to be promptly restored, but less than onethird of the observed calcium losses was replaced during observations that lasted as long as 42 days after $\mathrm{NH}_{4} \mathrm{Cl}$ loading was stopped.

The constant whole food diets used in these ex- periments provided a significant quantity of potential alkali as combustible anions, and during acid loading the fecal excretion of organic anions declined significantly.

During $\mathrm{NH}_{4} \mathrm{Cl}$ loading, net fixed acid production was increased by an average of $3,425 \mathrm{mEq}$. Most of this acid load was excreted by the kidneys, but at the end of 12 recovery days an average of $193 \mathrm{mEq}$ of the acid fed had not been excreted in the urine, despite the return of the serum bicarbonate to stable control levels. The simultaneous calcium balances averaged $-185 \mathrm{mEq}$, supporting the previous suggestion that bone mineral is an important buffer reservoir in the defense against chronic metabolic acidosis.

\section{References}

1. Swan, R. C., and R. F. Pitts. Neutralization of infused acid by nephrectomized dogs. J. clin. Invest. 1955, 34, 205.

2. Schwartz, W. B., K. J. Ørning, and R. Porter. The internal distribution of hydrogen ions with varying degrees of metabolic acidosis. J. clin. Invest. 1957, 36, 373.

3. Lemann, J., Jr., E. J. Lennon, A. D. Goodman, J. R. Litzow, and A. S. Relman. The net balance of acid in subjects given large loads of acid or alkali. J. clin. Invest. 1965, 44, 507.

4. Lennon, E. J., J. Lemann, Jr., and J. R. Litzow. The effects of diet and stool composition on the net external acid balance of normal subjects. J. clin. Invest. 1966, 45, 1601.

5. Farquharson, R. F., W. T. Salter, D. M. Tibbetts, and J. C. Aub. Studies of calcium and phosphorus metabolism. XII. The effect of the ingestion of acid-producing substances. J. clin. Invest. 1931, $10,221$.

6. Jaffe, H. L., A. Bodansky, and J. P. Chandler. Ammonium chloride decalcification, as modified by calcium intake: the relation between generalized osteoporosis and ostitis fibrosa. J. exp. Med. 1932, 56, 823.

7. Dennig, H., D. B. Dill, and I. H. Talbott. Bilanzuntersuchung einer Salmiakazidose. Archiv für experimentelle Pathologie und Pharmakologie 1929, 144, 297.

8. Albright, F., and E. C. Reifenstein, Jr. The Parathyroid Glands and Metabolic Bone Disease. Baltimore, Williams and Wilkins, 1948, p. 242.

9. Irving, L., and A. L. Chute. The participation of the carbonates of bone in the neutralization of ingested acid. J. cell. comp. Physiol. 1932-33, 2, 157.

10. Pellegrino, E. D., and R. M. Biltz. The composition of human bone in uremia. Observations on the reservoir functions of bone and demonstration of a labile fraction of bone carbonate. Medicine (Baltimore) $1965,44,397$. 